\title{
The Neurotrophic Factor Concept: A Reexamination
}

\author{
Sigrun Korsching \\ Max-Planck-Institut für Entwicklungsbiologie, Abteilung Physikalische Biologie, D-7400 Tübingen, Germany
}

The neurotrophic factor concept in its basic form envisages that innervated tissues produce a signal for the innervating neurons for the selective limitation of neuronal death occurring during development (Purves, 1986; Oppenheim, 1991). This concept arose several decades ago on the basis of the observation that experimental manipulation of the amount of target tissue could modulate the size of neuronal populations. By making the survival of neurons dependent on their target, nature would provide a means to match neuron and target cell populations.

NGF, discovered in the 1950 s, represents the first known molecular realization of the neurotrophic factor concept. NGF was found to regulate survival, neurite growth, and neurotransmitter production of a particular neuronal type, the sympathetic neurons of the PNS. NGF produced by target cells is specifically bound and internalized by sympathetic neurons, followed by retrograde axonal transport of NGF to the cell soma, where NGF exerts its effects via the cotransported receptor molecule (Levi-Montalcini, 1987; Thoenen et al., 1987). Strictly speaking, increased neurite growth and neurotransmitter production are not trophic effects; however, I will use the term "neurotrophic" in the extended meaning of enhancing neuronal differentiation as well as neuronal survival.

It was expected that these results could be generalized to a model of multiple, mutually independent, retrograde trophic messengers, which are synthesized in distinct target areas and act on restricted neuronal types (Fig. 1). This assumption leads to a conceptually simple way to arrange and maintain a variety of neuronal subsystems. One might call this a modular approach to the construction of the nervous system. The hypothesis of multiple retrograde signals has gained widespread experimental support in recent years. Originally proposed for the PNS, the model could be cxtended to the CNS, in which target neurons synthesize trophic factors for their afferent neurons (Ernfors et al., 1990h). In addition to NGF, a family of NGF-related molecules (now commonly called neurotrophins), which are thought to exert retrograde trophic influences (DiStefano et al., 1992), has been identified.

Key words: brain-derived neurotrophic factor, cholinergic differentiation factor, ciliary neurotrophic factor, fibroblast growth factor, leukemia inhibitory factor, neurotroph, neurotrophin, NGF, neurotrophin-3, receptor, review

It is a pleasure to thank Dr. Walter Nadler for valuable discussions, and Dr. Friedrich Bonhoeffer for generous support.

Correspondence should be addressed to Sigrun Korsching, Max-Planck-Institut für Entwicklungsbiologie, Abteilung Physikalische Biologie, Spemannstrasse 35/ I, D-7400 Tübingen, Germany.

Copyright (C) 1993 Society for Neuroscience $0270-6474 / 93 / 132739-10 \$ 05.00 / 0$
However, the recent barrage of publications dealing with neurotrophic factors has pointed to some limitations of the modular neurotrophic factor approach. Neurons might derive trophic support not only from innervated cells (retrograde mechanism), but also from afferent neurons (anterograde influence), axonensheathing glial cells, or even themselves (autocrine mechanism) (Fig. 2). Considerable evidence for these nonclassical trophic interactions has accumulated in the meantime. Neurotrophic factors also interacted much less specifically than a modular approach would call for. A given neurotrophic factor affects many neuronal types, and a given neuronal type is influenced by several neurotrophic factors. Instead of clear demarcations, nature has opted for a fuzzy strategy (Fig. 1). The pleiotropism of neurotrophic factors is equaled by their and their receptors' broad tissue distribution. In view of this apparent lack in specificity of interactions, we may ask to what extent neurotrophic interactions contribute to the highly specific connectivity of the nervous system.

Here I highlight some of the recent findings that demonstrate the complexity of neurotrophic factor interactions and their ostensible lack of specificity. I will present an integrated assessment of these observations and suggest a modified neurotrophic factor theory to reconcile the new data. My examples will be limited to the neurotrophins, ciliary neurotrophic factor (CNTF), lcukcmia inhibitory factor (LIF), and the fibroblast growth factor (FGF) family. Although not complete, this list of molecules with neurotrophic activities is of sufficient complexity to present a formidable challenge.

\section{The neurotrophins, CNTF, LIF, the FGF family, and their receptors}

The neurotrophin family contains five closely related factors: the prototype neurotrophic factor NGF (Levi-Montalcini, 1987), brain-derived neurotrophic factor (BDNF), neurotrophin-3, -4, and -5 (NT-3, NT-4, NT-5) (Leibrock et al., 1989; Hohn et al., 1990; Maisonpierre et al., 1990b; Berkemeier et al., 1991; Hallböök et al., 1991). The responsiveness of neurons and neuronal precursor cells to neurotrophins is summarized in Table 1. Two unrelated types of receptors have been identified for the neurotrophins. One is the low-affinity NGF receptor, also known as low-affinity neurotrophin receptor (LANR) (Radeke et al., 1987; Yarden and Kelman, 1991; Rodríguez-Tébar et al., 1992). The trk family of tyrosine kinases constitutes the other type of neurotrophin receptors and currently numbers three members, trkA, trkB, and trkC (Cordon-Cardo et al., 1991; Lamballe et al., 1991; Soppet et al., 1991). The relationship between trks and LANR is unclear, since complex formation between both types of receptors has not been observed (Radeke and Feinstein, 

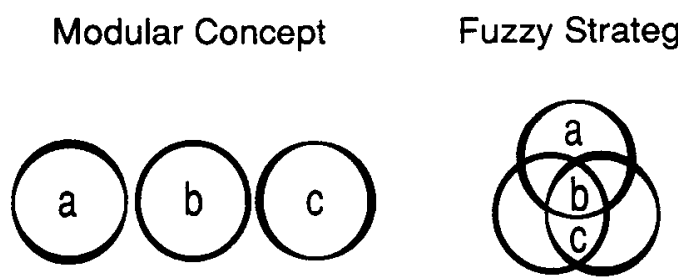

Figure 1. Schematic representation of possible interrelations between various neuronal types and neurotrophic factors. Different neurotrophic factors are represented by circles and different neuronal types by letters. The modular concept specifies individual neurotrophic factors for each neuronal type. The modified model allows for extensive overlap of responsiveness to different neurotrophic factors. A particular neurotrophic factor maintains more than one neuronal type. Neurons may be responsive to a single neurotrophic factor $(a)$ or to different combinations $(b, c)$.

1991). It has been suggested that signal transduction by neurotrophins is achieved solely by the trk family of receptors, without contribution of the LANR (Klein et al., 1991; Ibáñez et al., 1992). However, other experiments show the LANR as a necessary, though insufficient, component of signal transduction (Wright et al., 1992). LANR is required for survival of sympathetic and sensory neurons in vivo, albeit not in vitro (Johnson et al., 1989; Weskamp and Reichardt, 1991; Lee et al., 1992), and hence might be involved in the retrograde axonal transport of the neurotrophin/receptor complex.

Ciliary neurotrophic factor was so named for its ability to rescue cultured ciliary neurons (Barbin et al., 1984). As with NGF, FGF, and LIF, the naming proved to be premature, since CNTF additionally acts on a broad range of neuronal and even glial cells (Table 1; Anderson, 1989). The receptor for CNTF seems to be a heterotrimer of one membrane-linked, ligandbinding subunit and two transmembraneous, signal-transducing subunits (Davis et al., 1991; Ip et al., 1992). Avian growthpromoting activity (GPA), which is $50 \%$ homologous to mammalian CNTF and has similar biological activities, may constitute a second member of the CNTF family (Leung et al., 1992).

Leukemia inhibitory factor is a pleiotropic molecule with a multitude of effects for neurons and non-neuronal cells (Table 1), producing blockage or enhancement of differentiation or proliferation, depending on the responsive cell population (Smith et al., 1992). Peptide sequence and structure comparisons group LIF with several other cytokines and CNTF into a rather divergent family (Bazan, 1991). Possible ncurotrophic activities of the other cytokines have just begun to be studied (Satoh et al., 1988). The receptor for LIF contains a ligand-binding and a signal-transducing subunit, both of which belong to the gp130 family of cytokine receptors (Gearing et al., 1991, 1992).

Fibroblast growth factors have been characterized by virtue of their mitogenic activities for a variety of cell types of mesodermal and ectodermal origin (Rifkin and Moscatelli, 1989; Vlodavsky et al., 1991). Basic FGF (bFGF) enhances survival and differentiation of many neuronal types (Table 1). bFGF and acidic FGF (aFGF) turned out to belong to a family of growth factors that now numbers seven members (Vlodavsky et al., 1991). The possible neurotrophic activities of other family members have not been studied so far. Four high-affinity receptors for the FGF family have been cloned, forming a family of transmembrane proteins with ligand-activated tyrosine ki-

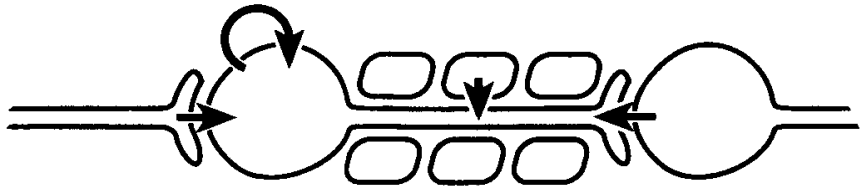

Figure 2. Schematic representation of possible sources for trophic support. The center neuron is drawn as member of a neuronal chain, with glial cells cnshcathing its axon. The ncuron might obtain trophic substances via anterograde transport from the afferent neuron, by means of an autocrine loop, from ensheathing glia cells, or by retrograde axonal transport from the neuron it innervates (classic notion). Trophic influence is shown by arrows.

nase activity (Klagsbrun and Baird, 1991; Yarden and Kelman, 1991).

These sketches of neurotrophic factors should provide sufficient background information for a detailed assessment of neurotrophic factor complexities in the following paragraphs.

\section{Modes of action of neurotrophic factors}

Retrograde messenger mechanism. This is the classical pathway for mediating neurotrophic influences (Fig. 2). It comprises synthesis of a neurotrophic factor in target cells of the responsive neuron, secretion as a soluble form into the extracellular space, receptor-mediated uptake, and retrograde axonal transport toward the soma of the responsive neuron. All components of this pathway have been identified in the case of NGF and sympathetic, sensory, and magnocellular cholinergic neurons (Levi-Montalcini, 1987; Thoenen et al., 1987). Deprivation of endogenous NGF mimics interruption of retrograde axonal transport; that is, NGF constitutes the endogenous retrograde trophic messenger for these neurons (Levi-Montalcini et al., 1987; Vantini et al., 1989). Sensory neurons receive a trophic signal via their central connections in the spinal cord, which is not NGF, but may be BDNF (Lindsay, 1988; Maisonpierre et al., 1990a). Strong support for positing a role as retrograde trophic messenger is provided by retrograde axonal transport of the factor, which has been demonstrated for NGF, BDNF, NT3 , and LIF in several neuronal types (Korsching, 1986; DiStefano et al., 1992; Hendry et al., 1992).

Do anterograde trophic messengers exist? Many neuronal types depend on afferent input for their survival, as shown by anterograde degeneration after lesioning afferent input (Oppenheim, 1991). This widespread phenomenon implies the existence of anterograde trophic signaling. Neurotransmitter molecules that are delivered anterogradely could exert trophic influences in addition to their function in transduction of electrical signals. Indeed, effects on neuronal survival and differentiation have been described for classical as well as peptide neurotransmitters (Lipton and Kater, 1989). Furthermore, neurons might exert long-range anterograde neurotrophic influences on their target neurons via anterograde axonal transport of macromolecular substances (Fig. 2). FGF could be a candidate anterograde trophic messenger. bFGF is synthesized and released by retinal cells in vivo (Hageman et al., 1991) and exogenous bFGF is transported anterogradely in retinal ganglion cell axons toward the superior colliculus (Ferguson et al., 1990), which depends on afferent input for survival of its neurons.

Local action of neurotrophic factors. Endogenous NGF exerts a neurotrophic effect on striatal cholinergic interneurons (Mobley et al., 1989; Vantini et al., 1989). This effect implies a local 
Table 1. Responsiveness of neurons and neuronal precursor cells to various neurotrophic factors

\begin{tabular}{|c|c|c|c|c|c|c|c|c|}
\hline & $\mathrm{NGF}^{\prime}$ & $\mathrm{BDNF}^{2}$ & NT-3 $3^{3}$ & NT-4 & NT $-5^{s}$ & $\mathrm{CNTF}^{6}$ & LIF $^{7}$ & $\mathrm{bFGF}^{8}$ \\
\hline \multicolumn{9}{|l|}{ Neurons of the peripheral nervous system } \\
\hline Ciliary ganglion (parasympathetic) ${ }^{a}$ & -- & -- & $-?$ & $\cdots \cdots$ & -- & $+\cdots$ & $-\cdots$ & $+\cdots$ \\
\hline Dorsal root ganglion (sensory) ${ }^{b}$ & $+t$ & ++ & ++ & $\cdots+$ & ++ & $+\cdots$ & ++ & $+\cdots$ \\
\hline Ganglion of Remak (enteric) & $\cdots<$ & $\cdots \cdots$ & $\cdots+$ & $\cdots \cdots$ & $\cdots \cdots$ & $\cdots \cdots$ & $\cdots \cdots$ & $\cdots \cdots$ \\
\hline Nodose ganglion (sensory) ${ }^{d}$ & $-<$ & ++ & ++ & $\cdots<$ & $-\cdots$ & $-\cdots$ & $\cdots \cdots$ & $\cdots \cdots$ \\
\hline Pheochromocytoma cell (PC12) & +++ & $\cdots--$ & $\cdots ? ?$ & $\cdots--$ & $\cdots++$ & $\ldots \ldots \cdots$ & $\ldots \ldots \ldots$ & +++ \\
\hline \multicolumn{9}{|l|}{ Neurons of the central nervous system } \\
\hline Cholinergic interneuron (striatum) $)^{h}$ & ++ & $\cdots \cdots$ & $\cdots \cdots$ & $\cdots \cdots$ & $\cdots \cdots$ & $\cdots+$ & $\cdots-$ & $\cdots \cdots$ \\
\hline GABAergic neuron (basal forebrain) ${ }^{i}$ & $-\infty$ & $\cdots+$ & $\cdots \cdots$ & $\cdots \cdots$ & $\cdots \cdots$ & $+\cdots$ & $\cdots \cdots$ & $\cdots+$ \\
\hline Granule cell (cerebellum) & -- & $+\cdots$ & $-\cdots$ & $\cdots \cdots$ & $\cdots \cdots$ & $\cdots \cdots$ & $\cdots \cdots$ & ++ \\
\hline Mesencephalic dopaminergic neuron (substantia nigra) ${ }^{k}$ & $\cdots-$ & $+\cdots$ & $\cdots-$ & $\cdots \cdots$ & $\cdots \cdots$ & $\cdots \cdots$ & $\cdots \cdots$ & -- \\
\hline Sympathetic preganglionic neuron ${ }^{p}$ & $-\cdots$ & $\cdots \cdots$ & $\cdots \cdots$ & $\cdots \cdots$ & $\cdots \cdots$ & $+\cdots$ & $\cdots \cdots$ & $+\cdots$ \\
\hline \multicolumn{9}{|l|}{ Neuronal precursor cells } \\
\hline Chromaffin, precursor cell ${ }^{a}$ & +++ & $\ldots \ldots \ldots$ & $\ldots \ldots \ldots$ & $\cdots \cdots$ & $\cdots \cdots$ & $\cdots \ldots$ & $\ldots \ldots \ldots$ & $\cdots++$ \\
\hline Neural crest cell ${ }^{r}$ & --- & -+- & $\cdots \cdots+$ & $\cdots \cdots$ & $\cdots \cdots$ & $\cdots \cdots \cdots$ & -+- & $+\cdots-$ \\
\hline Neuroepithelial stem cells & $\cdots++$ & $\ldots \ldots \ldots$ & $\ldots \ldots \ldots$ & $\cdots \cdots$ & $\cdots \cdots$ & $\ldots \ldots \ldots$ & $\ldots \ldots \ldots$ & +++ \\
\hline Sensory ganglion precursor cell ${ }^{t}$ & $-+\cdots$ & $-+\cdots$ & $-+\cdots$ & $\cdots \cdots$ & $\cdots \cdots$ & $\cdots \cdots \cdots$ & $+\cdots-$ & $\cdots+\cdots$ \\
\hline Sympathetic ganglion precursor cell ${ }^{u}$ & $-<-$ & $\cdots \cdots-$ & $\ldots \ldots \ldots$ & $\ldots \ldots$ & $\ldots \ldots$ & $\cdots++$ & $\ldots \ldots \ldots$ & $\cdots \cdots-$ \\
\hline
\end{tabular}

Effects on survival and differentiation are listed separately, in that order. For neuronal precursor cells and PCI2 cells, effects on proliferation are listed in the third position. + indicates the presence of a biological response; < indicates a small, but significant effect; - indicates the absence of an effect; ? indicates controversial findings; stands for not determined. a1, Eckenstein et al., 1990. a2, Maisonpierre et al., 1990b. a3, Ernfors et al., 1990a; Hohn et al., 1990; Maisonpicrre ct al., 1990b. a5, Berkemeier et al., 1991. a6, Lin et al., 1990. a7, Rao et al., 1990. a8, Eckenstein et al., 1990. b1, Lindsay, 1988; Diamond et al., 1992; Ruit et al., 1992. b2, Lindsay, 1988; Leibrock et al., 1989. b3, Maisonpierre et al., 1990b; Rosenthal et al., 1990. b4, Hallböök et al., 1991. b5, Berkemeier et al., 1991. b6, Lin et al., 1990. b7, Murphy et al., 1991. b8, Eckenstein et al., 1990. c1, c3, Ernfors et al., 1990a. dI, Katz et al., 1990; Rosenthal et al., 1990. d2, Hohn et al., 1990; Maisonpierre et al., 1990b. d3, Rosenthal et al., 1990. d4, Hallböök et al., 1991. d5, Berkemeier et al., 1991. d6, Barbin et al., 1984. e1, Levi-Montalcini, 1987. e2, Squinto et al., 1991. e3, Rosenthal et al., 1990; Squinto et al., 1991. e4, Klein et al., 1992. e5, Berkemeier et al., 1991. e8, Rydel and Greene, 1987. fl, Levi-Montalcini, 1987; Ruit et al., 1990; Campenot et al., 1991. $f 2$. Lindsay et al., 1985; Maisonpierre et al., 1990b. $f 3$. Hohn et al., 1990; Rosenthal et al., 1990. $f 4$, Hallböök et al., 1991. $f 5$, Berkemeier et al., 1991. f6, Lin et al., 1990; Rao et al., 1990. $f 7$, Transdifferentiation from noradrenergic to cholinergic phenotype, Yamamori et al., 1989. $f 8$, Eckenstein et al., 1990. gl, g2, Lindsay, 1988. g3, Hohn et al., 1990. hI, Mobley et al., 1989; Vantini et al., 1989. h6, Hagg et al., 1992. h7, Martinou et al., 1992. il, Knüsel et al., 1991; Hagg et al., 1992. i2, Knüsel et al., 1991. i6, Hagg et al., 1992. i8, Knüsel et al., 1991. j1, Hatten et al., 1988. j2, j3, Segal et al., 1993. j8, Hatten et al., 1988. $k I$, Knüsel et al., 1991. $k 2$, Hyman et al., 1991. k3, Knüsel et al., 1991. $k 8$, Engele and Bohn, 1991. 11, Korsching, 1986; Vantini et al., 1989; Fischer et al., 1991. 12 , Alderson et al., 1990. 13, Knüsel et al., 1991. 16, Hagg et al., 1992. l7, Martinou et al., 1992. 18, Knüsel et al., 1991. ml, Arakawa et al., 1990. Most labs do not observe a differentiating effect, but see Wayne and Heaton, 1990. $m 2, m 3$, DiStefano et al., 1992; Sendtner et al., 1992. $m 5$, Berkemeier et al., 1991. $m 6$, Arakawa et al., 1990; Gurney et al., 1992. $m$ 7, Martinou et al., 1992. $m 8$, Arakawa et al., 1990; Gurney et al., 1992. $n 1$, Cohen-Cory et al., 1991. o1, o2, Rodriguez-Tébar et al., 1989. o6, Stöckli et al., 1991. o8, Lipton et al., 1988. p1, p6, p8, Blottner et al., 1989. $q 1$, Lillien and Claude, 1985. $q 8$, Birren and Anderson, 1990. $r 1, r 2$, Sieber-Blum, 1991. $r 3$, Kalcheim et al., 1992. $r$, Murphy et al., 1991. r8, Kalcheim, 1989. sI, Cattaneo and McKay, 1990. s8, Drago et al., 1991.t1, $t 2, t 3$, Ernsberger and Rohrer, 1988; Wright et al., 1992. $t$, Murphy et al., 1991. 18 , Stocker et al., 1991. $u 1, u 2$, Ernsberger et al., 1989a. $u 6$, $u 8$, Ernsberger et al., $1989 \mathrm{~b}$.

mode of action, since the targets of these interneurons are contained within the corpus striatum. The closely apposed granule and Purkinje cells of the cerebellum seem to constitute another local neurotrophic system. In vivo, granule cells depend on Purkinje cells for survival (Herrup and Sunter, 1987). Endogenous aFGF, int- 2 of the FGF family, BDNF, and NT-3 are plausible candidates for mediating this interaction (Hatten et al., 1988; Wilkinson et al., 1989; Maisonpierre et al., 1990a; Lamballe et al., 1991; Schnürch and Risau, 1991; Gómez-Pinilla et al., 1992; Scgal et al., 1993).

Nerve sheath as source of neurotrophic factors. The rate of synthesis of NGF in ensheathing cells of peripheral nerve is high during development and decreases during adulthood. However, it rises again transiently after nerve lesion (Heumann et al., 1987). This means that NGF is provided locally along the nerve (Fig. 2) while target innervation is incomplete during development, or before contact with the target organs is reestablished during regeneration. Nerve sheath NGF is taken up by regenerating axons and may enhance regeneration of injured neurons (Brown et al., 1991; but see Diamond et al., 1992).

Glial cells as mediators of indirect neurotrophic effects. Glial cells are known to synthesize neurotrophic factors (Hatten et al., 1988; Yoshida and Gage, 1991), and in some cases mediate the neurotrophic action of bFGF (Engele and Bohn, 1991). FGF enhances the NGF release of astrocytes (Yoshida and Gage, 1991) and may also act via its mitogenic effect on glial cells (Engele and Bohn, 1991). This neurotrophic mechanism is indirect but may be physiologically relevant, for cxample, after injury-induced reactive astrocytosis in the CNS.

Neurons as origin of neurotrophic factors. Traditionally, the source of neurotrophic factors was thought to be the non-neuronal cells of target organs and of the nerve sheath. The synthesis of NGF in target organs of sympathetic and sensory neurons and in injured peripheral nerve confirmed this assumption (Korsching and Thoenen, 1983; Heumann et al., 1987). It was therefore surprising that a variety of neurotrophic factors are 
produced by neurons in both the CNS and PNS. Several members of the FGF family are synthesized by neurons (Wilkinson et al., 1989; Elde et al., 1991; Schnürch and Risau, 1991). The synthesis of NGF and BDNF in pyramidal and granule neurons of the hippocampus (Ernfors et al., 1990b) agrees with the proposed role as retrograde trophic messengers for their afferents, the magnocellular cholinergic neurons. Preliminary evidence indicates neuronal BDNF secretion at the cell soma or dendrites, but presumably not at the axon (Wetmore et al., 1991). If the release is restricted to particular subcellular regions, for example, synaptic sites, a trophic interaction could be localized essentially to an individual neuron chain.

Autocrine mode of action. Some types of neurons not only synthesize neurotrophic factors but also express the cognate receptors and respond to their own neurotrophic factors. For example, coexpression of a member of the FGF family together with a receptor for FGF occurs in sensory neurons and motoneurons (Heuer et al., 1990; Elde et al., 1991; Schnürch and Risau, 1991). Dorsal root ganglion neurons, sympathetic neurons, and hippocampal pyramidal neurons synthesize both BDNF and its receptor, trkB (Ernfors et al., 1990b; Klein et al., 1990b; Wetmore et al., 1991; Schecterson and Bothwell, 1992). BDNF and its receptor may even be colocalized within single neuronal cells (Schecterson and Bothwell, 1992; Wright et al., 1992). Such an autocrine mechanism obviously cannot mediate target-neuron interactions but may serve to maintain neurons until target contact is established. Also, the neurotrophic molecules released by any one neuron are presumably accessible for the entire population of neurons, so that cellular properties within the neuronal type will be equalized.

Do nonsecreted neurotrophic factors exist? The autocrine interaction described above still requires secretion of the neurotrophic factor by the neuron synthesizing it. Whether some of the neurotrophic factors are secreted at all has been controversial. CNTF, bFGF, and aFGF all lack the N-terminal signal sequence, thought to be necessary for secretion (Stöckli et al., 1991; Vlodavsky et al., 1991). Moreover, CNTF and FGF have not been detected in medium conditioned by cells synthesizing these factors (but see Araujo and Cotman, 1992; Jackson et al., 1992). However, several proteins missing conventional signal sequences are known to be extruded from intact cells (Muesch et al., 1990). Also, a secreted factor might escape detection by immobilization on either the extracellular matrix or the cell surface. FGF binds to proteoglycans of the extracellular matrix, and the widespread occurrence of bFGF in extracellular matrices in vivo argues for the existence of an as yet uncharacterized release mechanism for bFGF (Rifkin and Moscatelli, 1989; Vlodavsky et al., 1991). Another possibility would be that the neurotrophic activities of CNTF, bFGF, and aFGF mimic those of other family members that do possess signal sequences and are secreted (Rifkin and Moscatelli, 1989; Leung et al., 1992). If the intracellular destination of CNTF, of some forms of FGF (Elde et al., 1991), and possibly of one form of BDNF (Wetmore et al., 1991) are corroborated in future experiments, the question of the function of an intracellular neurotrophic factor will have to be addressed. It is conceivable that such a factor is kept in store to be released upon nerve lesion. However, a reduction of CNTF synthesis after lesion seems to argue against its function in nerve regeneration (Friedman et al., 1992). Another possibility is the intracrine function of a neurotrophic factor in the cell synthesizing it, analogous to the intracrine mitogenic effects of bFGF and aFGF (Rifkin and Moscatelli, 1989).

\section{Pleiotropy and redundancy of neurotrophic factors}

A single neurotrophic factor exerts a diversity of effects on a single neuronal type. For example, in sensory neurons NGF enhances survival (Lindsay, 1988), and also stimulates neurite initiation, branching, and elongation (Diamond et al., 1992), neurofilament synthesis (Katz et al., 1990), and synthesis of several neuropeptides (Levi-Montalcini, 1987). NGF is a chemotactic attractant of growth cones of sensory neurons (Levi-Montalcini, 1987), although no use is made of this property in establishing initial target contact (Vogel and Davies, 1991). This diversity of effects seems to be generated by coupling the initial NGF signal to different intracellular signaling pathways (Greene et al., 1990) and by localizing some responses to the growth cone and others to the soma (Campenot et al., 1991; Meiri and Burdick, 1991).

A single neurotrophic factor influences a diversity of neuronal types. Each column of Table 1 presents the neuronal types responsive to a particular neurotrophic factor. All neurotrophic factors listed there affect several neuronal types and most affect additional neuronal types not included in Table 1. Responsiveness to any particular factor does not follow a recognizable pattern: it is correlated with neither transmitter phenotype nor cell lineage. Adrenergic, cholinergic, and peptidergic neurons may all respond to the same neurotrophic factor, as may placode-derived as well as neural crest-derived neurons and peripheral as well as central neurons (Table 1). Thus, several neuronal types may share a common source, and so compete, for the same endogenous neurotrophic factor (Korsching and Thoenen, 1985). Such competition might serve to regulate the relative ahundance of different neuronal types.

A single neurotrophic factor influences neuronal and non-neuronal cells. NGF enhances the proliferation and blocks differentiation of some neuronal precursor cells (Table 1). BDNF and NT-3 exhibit differentiation-enhancing and mitogenic activity for neuronal precursor cells (Table 1). Several non-neuronal cell types, including some of the immune system, respond to NGF in vitro (Pearce and Thompson, 1986; Otten et al., 1989; Saad et al., 1991; Yaar et al., 1991). If these observations can be substantiated by in vivo experiments, NGF would not be a purely neuronal factor, but a mixed-function molecule like FGF and LIF. In addition to their manifold effects on non-neuronal cells (Ritkin and Moscatelli, 1989; Vlodavsky et al., 1991; Smith et al., 1992), FGF and LIF enhance survival and differentiation of several neurons and neuronal precursor cells (Table 1). Furthermore, FGF enhances proliferation of some neural precursor cells and glial cells (Table 1) (Engele and Bohn, 1991). Besides its effects on a variety of neuronal types, CNTF affects both neuronal precursor cells and glial cells (Table 1; Anderson, 1989; Ernsberger et al., 1989b). These results imply that the distinction between neuron-specific and non-neuronal trophic factors is vanishing. All neurotrophic molecules additionally possess mitogenic or differentiation activities for neuronal precursor cells, and some also influence proliferation and differentiation of glial cells and multiple non-neural cell types.

Different neurotrophic factors show overlapping, yet distinct patterns of activities. Table 1 details this statement for the neurotrophins. In the FGF family, aFGF has similar, but not identical, neurotrophic activities to bFGF (Lipton et al., 1988). Considerable overlap of activities is observed even between different neurotrophic families. Dorsal root ganglion neurons, for example, are responsive to all neurotrophic factors listed in Table 
1. The overlapping activities are reflected in the convergence of intracellular signal transduction pathways (Chao, 1992). Furthermore, neurotrophins cause proliferation rather than neuronal differentiation in non-neuronal cells transfected with their cognate receptor genes (Cordon-Cardo et al., 1991; Klein et al., 1991; Lamballe et al., 1991). It seems that neurons adapt common signaling mechanisms for their particular differentiation, instead of depending on unique signal transduction pathways.

Apparent and true redundancy of neurotrophic factors. In cases where redundancy of neurotrophic factors is observed, it may turn out to be apparent only. For example, both FGF and CNTF increase survival of motoneurons (Arakawa et al., 1990). Howcver, FGF rescues a different subpopulation of motoneurons than does CNTF, as can be inferred from the additivity of their effects. Another case in point is the survival of dorsal root ganglion neurons elicited by both BDNF and NGF (Leibrock et al., 1989). Each factor by itself rescues only a subpopulation of neurons, and only the combined presence of both factors achieves complete survival. In contrast, of the triple combination NGF, BDNF, and NT-3, one member is truly redundant with respect to survival since NT-3 also improves survival of dorsal root ganglion neurons. Similarly, BDNF and NT-3 are redundant with respect to survival of neurons of the trigeminal mesencephalic nucleus, since all neurons can be rescued by NT-3 alone (Hohn et al., 1990). True redundancy so far has been observed only in vitro. It remains to be seen whether this phenomenon also can be detected in vivo, where the expression pattern of neurotrophic factor receptors and signal transduction components may be different.

Different neurotrophic factors share receptors and their subunits. NGF, BDNF, NT-3, and NT-4 all bind to LANR (Table 2 ). The $t r k \mathrm{~A}$ and $t r k \mathrm{~B}$ receptors of the $t r k$ family bind more than one neurotrophin, and NT-3 and NT-5 bind to more than one type of $t r k$ receptor (Table 2 ). The much higher specificity of high-affinity binding to responsive neurons (Rodriguez-Tébar et al., 1992) might be achieved by a, so far speculative, interaction of trk receptors with LANR. Any particular FGF receptor binds more than one member of the FGF family with similar high affinity (Klagsbrun and Baird, 1991; Yarden and Kelman, 1991; Vainikka et al., 1992). Ligand-induced receptor dimerization is typical for tyrosine kinase receptors, and has been described for FGF/receptor complexes (Yarden and Kelman, 1991). The formation of a heterodimer receptor (Bellot et al., 1991 ) increases the complexity of possible FGF-receptor interactions. The signal-transducing component of the LIF and CNTF receptors is identical, and furthermore present in other cytokine receptors (Yarden and Kelman, 1991; Gearing et al., 1992; Ip et al., 1992). All subunits of the, presumably trimeric, CNTF and LIF receptors belong to cytokine receptor families (Davis et al., 1991; Gearing et al., 1991, 1992; Ip et al., 1992). Despite common signaling pathways, specificity of interactions still may be achieved by restricted expression of some receptor components (Davis et al., 1991).

\section{Complexity of neurotrophic factors and their interactions}

Spatial distribution pattern. Different neurotrophic factors and their receptors regulate their spatial distribution patterns differently. Most of them exhibit a distinct, although broad, tissue distribution (Heuer et al., 1990; Maisonpierre et al., 1990a; Stöckli et al., 1991; Gómez-Pinilla et al., 1992). Despite the broad distributions, the overlap between the expression pattern
Table 2. Receptor specificity of the neurotrophin family

\begin{tabular}{lllll} 
& $\operatorname{trkA}$ & $\operatorname{trkB}$ & $\operatorname{trkC}$ & LANR \\
\hline NGF & + & - & - & + \\
BDNF & - & + & - & + \\
NT-3 & $<$ & + & + & + \\
NT-4 & - & + & - & + \\
NT-5 & + & + & $\ldots$ & $\ldots$
\end{tabular}

+ indicates specific binding or a biological response via the receptor; < indicates a small but significant specific interaction; - indicates the absence of an interaction; and ... stands for not determined. Data are taken from Berkemeier et al., 1991; Cordon-Cardo et al., 1991; Hallböök et al., 1991; Klein et al., 1991; Lamballe et al., 1991; Soppet et al., 1991; Squinto et al., 1991; Klein et al., 1992; Rodríguez-Tébar et al., 1992

of a neurotrophic factor and its receptors could be limited. A receptor binding more than one neurotrophic factor will be de facto specific for the particular neurotrophic factor endogenously expressed in that region. For example, the restricted expression of NT-3 and NT-4 in the adult animal (Maisonpierre et al., 1990a; Hallböök et al., 1991) could entail increased de facto specificity of the multifunctional trk family of receptors (Table 2). An unexplainably broad distribution of a particular neurotrophic factor or receptor may indicate a hitherto unknown responsive cell population. For example, LANR has been detected on a variety of neurons, glial cells, and even non-neural cells, in fact, on many more cell types than those known to be responsive to NGF or another neurotrophin (Wheeler and Bothwell, 1992).

Temporal pattern of expression. This pattern is distinct for various neurotrophic factors and different tissues. Developmental regulation of synthesis varies for different neurotrophins (Maisonpierre et al., 1990a). Increases or decreases toward adult levels have been observed in different tissues for a particular neurotrophin or neurotrophin receptor (Heumann et al., 1987; Mobley et al., 1989; Heuer et al., 1990; Maisonpierre et al., 1990a). This specific spatiotemporal regulation of expression could ensure very restricted interactions of individual neurotrophins with neuronal types or even subtypes, although any given neurotrophin has a broad spectrum of responsive neurons. Temporal restriction of response has been observed for NGF (Lindsay, 1988), BDNF (Rodríguez-Tébar et al., 1989; Vogel and Davies, 1991), NT-3 (Wright et al., 1992), CNTF (Barbin et al., 1984), and FGF (Heuer et al., 1990). Many FGF-responsive neuronal types seem not to respond to aFGF or bFGF during the cell death period (Oppenheim et al., 1992).

Compartmentalization via molecular heterogeneity. The neurotrophins, LIF, several members of the FGF family, and some of their receptors are each encoded in several different kinds of mRNA, which may differ in their tissue distribution and function (Selby et al., 1987; Yarden and Kelman, 1991; Miki et al., 1992). The different mRNAs are generated by the initiation of transcription at different promoters and alternative mRN $\Lambda$ splicing. The two forms of LIF possess different signal sequences; one form is targeted to the extracellular matrix, whereas the other is soluble (Smith et al., 1992). In several members of the FGF family, initiation of translation at different codons causes either cytoplasmic, nuclear, or extracellular translocation of the protein (Acland et al., 1990). This segregation could serve to compartmentalize very disparate functions of the same type of neurotrophic molecule: neuronal precursor cells within germinal 


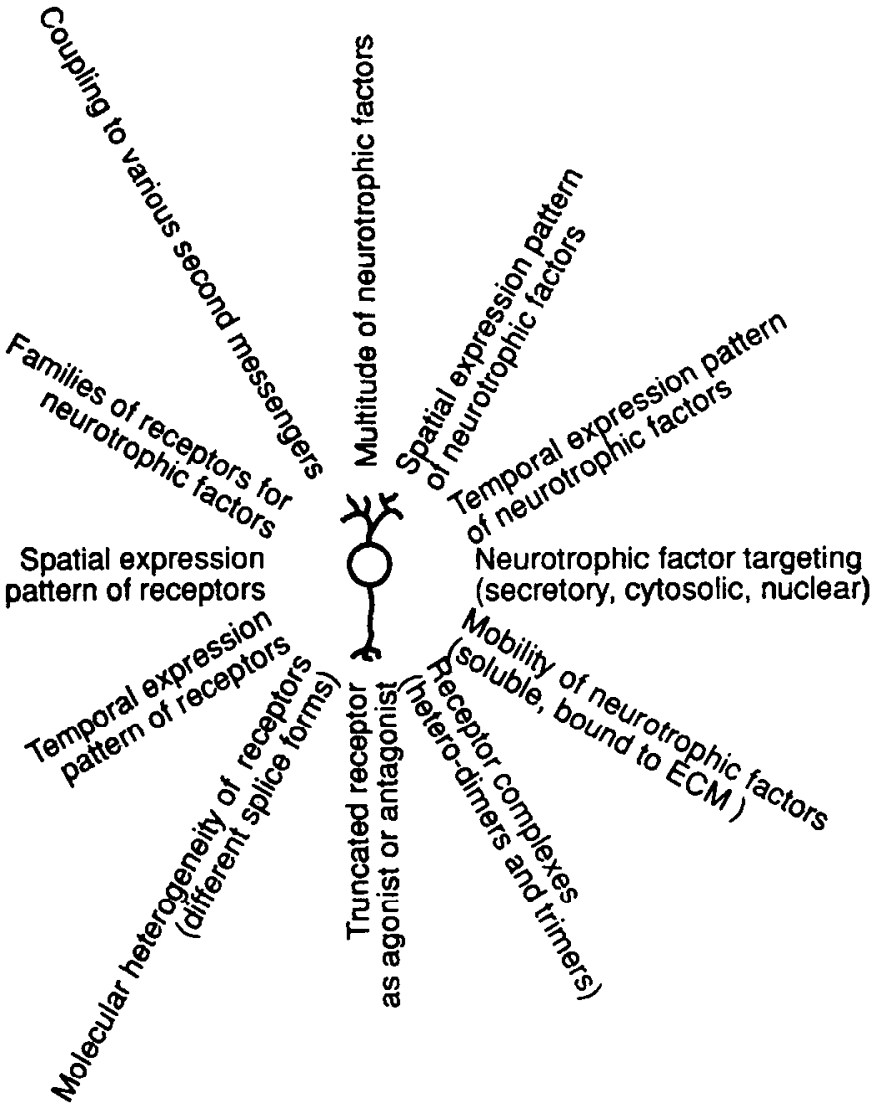

Figure 3. Multidimensionality of neurotrophic factor interactions. The neuron is schematically represented in the center of the figure. Each radius represents a different dimension of the multidimensional "neurotrophic state space" of the nervous system. Each dimension corresponds to a different variable, which can have continuous (e.g., space, time) or discrete (e.g., family of molecules) values. A particular neuronal type is characterized by a point in this neurotrophic state space. Any single value of a variable (e.g., expression of LANR) may be common to many neuronal types. However, the combination of values for all variables (c.g., expression of full-length LANR together with a truncated fragment of $t r k \mathrm{~B}$, but not $\operatorname{trk\mathrm {A}}$; BDNF, but not NT-3 synthesis, etc.) is presumably unique for a particular neuronal type or even subtype. In this way, very specific interactions can take place despite the pleiotropic nature of neurotrophic factors. To test this hypothesis, an integrated assessment of the above set of variables for particular neuronal types will be necessary.

zones may interact predominantly with trophic factors deposited into the adjacent extracellular matrix. Truncated fragments of the neurotrophin receptors LANR, $t r k B$, and the LIF receptor (Klein et al., 1990a; Gearing et al., 1991) could act either as agonist or antagonist when binding the ligand or upon association with a full-length receptor subunit (Yarden and Kelman, 1991). Therefore, in all such cases it will be necessary to elucidate the function and distribution pattern of the truncated fragments separately from that of the full-length receptor. Thus, alternative promoter usage, differential splicing, and alternative initiation of translation generate variations in tissue distribution, subcellular localization, mobility, and function of neurotrophic factors. This molecular heterogeneity is not usually taken into account when discussing the pattern of synthesis of a neurotrophic factor, in part because the functional consequence and physiological importance of most modifications is unknown. However, molecular heterogeneity seems to be spatiotemporally regulated, and compartmentalization of different subforms may serve to achieve higher specificity in the interactions of a single neurotrophic factor or receptor.

Sequences of differentiation or proliferation events involving two neurotrophic factors. The mitogenic response of neuronal precursor cells to NGF in cultures of striatal primordium requires previous exposure to FGF (Cattaneo and McKay, 1990). Neuroepithelial precursor cells require insulin-like growth factor I for survival in order to react to FGF with proliferation (Drago et al., 1991). FGF differentiates chromaffin precursor cells to sympathetic neurons, which become dependent on NGF upon this transition (Birren and Anderson, 1990). The transition of neural crest cells from proliferation to differentiation is antagonistically influenced by two neurotrophins (Sieber-Blum, 1991; Kalchcim et al., 1992). These multifactor intcractions add another level of complexity to the network of neurotrophic interactions.

Neuronal activity and neurotrophic factors regulate neurotrophic factors and their receptors. Synthesis of LIF and NGF is regulated by various other growth factors, including FGF, transforming growth factor, and interleukin-1 (Matsuoka et al., 1991; Smith et al., 1992). Sympathetic neurons synthesize interleukin-1, possibly to provide for their NGF supply (Freidin et al., 1992). Within the CNS, interleukin-1 could be involved in a positive feedback loop, since its synthesis is stimulated by NGF in astrocytes. A single factor can have opposite effects on NGF synthesis in different cell types (Matsuoka et al., 1991). Depolarization stimulates neuronal synthesis of NGF and BDNF, but not of NT-3 in the mature CNS or of trkA in a neural precursor cell line (Birren et al., 1992; Dugich-Djordjevic et al., 1992). Since the depolarization signal is only delivered at synaptic sites, this could represent a highly localized interaction (Castrén et al., 1992). Ligand-induced stimulation of receptor synthesis has been observed for NGF and LANR, and for NGF and trkA (Miller et al., 1991; Yaar et al., 1991; Holtzman et al., 1992). This kind of positive feedback reduces the threshold for subsequent stimulation by the ligand, thereby in effect facilitating the response.

\section{Making sense of neurotrophic interactions}

Our analysis so far has shown that neurotrophic interactions are both more complex and less specific than previously thought. Information transfer by neurotrophic molecules seems not to be restricted to the retrograde messenger mode, but may include local trophic interactions, autocrine signaling, and anterograde trophic signals. Successions of several neurotrophic interactions may be necessary for normal development of neuronal types. Both neurotrophic factors and their corresponding receptors can be grouped into families with overlapping as well as distinct activities. Particular neurotrophic factors exist in several forms, which can have different subcellular, extracellular, or tissue localization, and may perform different functions. A given neurotrophic factor may affect a variety of neuronal and non-neuronal cell populations, and can influence both differentiation and proliferation, depending on the targeted cell. This plethora of effects is mediated via receptor molecules, which are coupled to more than one intracellular signaling pathway. In several cases, the receptor is a multimer, and a particular subunit may be shared by different receptor complexes. Truncated receptor fragments may act as agonists or antagonists of neurotrophic factors. 
How can the nervous system develop and maintain a precise connectivity using pleiotropic factors with overlapping activities?

The actual specificity of neurotrophic interactions may be much higher than suggested at first sight by this survey if one takes into account the possibility of a detailed regulation of the spatial and temporal expression pattern for all modifications of neurotrophic factors, receptors, and intraccllular signaling components. The neurotrophic factors accessible to a particular neuronal type at a distinct spatiotemporal location will elicit effects according to the repertoire of receptors and intracellular signaling cascades expressed by that cell population. Furthermore, the interaction of several neurotrophic signals may lead to an unique influence for a particular neuronal type. It is now technically feasible to generate animals that lack certain neurotrophic factors or synthesize particular neurotrophic factors with an artificially altered pattern of spatiotemporal expression. This means that the hypothesis proposed here is amenable to experimental analysis in vivo.

Are there simplifying principles recognizable in the multicomponent system of neurons and neurotrophic factors?

Early attempts to categorize neuronal types according to their neurotrophic factor requirements have always been invalidated by the next round of experimental results. For example, responsiveness to NGF is not correlated with function, cell lineage, or transmitter phenotype: NGF-responsive neurons belong to afferent and efferent systems, to neural tube and neural crest derivatives, to cholinergic, adrenergic, and peptidergic neuronal types (Table 1). It is not even evident that a mapping of neurotrophic requirements onto neuronal type should he possible. The evolutionary process could have changed early-existing correlations beyond recognition. On the other hand, we might assume that the developmental mechanisms responsible for specifying a particular neuronal type, that is, a particular gene expression pattern, would also be involved in specifying the neurotrophic factor requirements of that neuronal type. Such a correlation has not becn found by single factor analysis as described above, but it may be possible in the future to reveal a hidden pattern by an integrated assessment of the available data.

The interaction of a neuron with neurotrophic factors consists of several molecular components: particular neurotrophic factor(s), receptor(s) for neurotrophic factors, intracellular transport mechanism, and intracellular signal transduction pathways. As shown above, molecular heterogeneity has been observed for several neurotrophic factors and receptors. All of these components can be thought of as a set of variables, which together define a multidimensional "neurotrophic state space" for neurons (Fig. 3). A particular neuronal type will have particular coordinates in this state space, which correspond to the set of conditions experienced by that neuronal type. Modern methods of statistical analysis could detect whether related neuronal types are clustered in this state space or are distributed randomly. Unfortunatcly, the present state of knowledge is too anecdotal to sustain a valid mathematical treatment of this problem. The amount of information still lacking is evident from the many missing entries in Table 1 . Also, much of the available information has been obtained in vitro, where expression patterns may deviate considerably from the in vivo situation. The absence of a biological effect, as important as its presence for such a theoretical analysis, is not usually examined with the same degree of persistence.

\section{Conclusions}

Neurotrophic factors were once thought of as specialized, targetderived molecules, each mediating survival and enhancing differentiation of well-defined and distinct neuronal types. With the increasingly detailed examination of neurotrophic interactions and the wealth of experimental data accumulated in the meantime, it becomes clear that this concept has to be modified. Neurotrophic factor interactions are less specific and more complex than has been assumed. Characteristic features are a high degree of pleiotropism and, accordingly, a considerable overlap in biological activities. Signaling by neurotrophic molecules seems not to be restricted to the retrograde messenger mode but may include local trophic interactions, autocrine signaling, and anterograde trophic signals. Molecular heterogeneity is observed for most constituents of the neurotrophic interaction. All these properties can be thought of as variables in a multidimensional ncurotrophic state space in which each neuronal type is characterized by a combination of values for these variables, as schematically depicted in Figure 3. A high degree of specificity can be achieved by detailed regulation of the spatial and temporal expression pattern for all modifications of neurotrophic factors, receptors, and intracellular signaling components. The neurotrophic factors accessible to a particular neuronal type at a distinct spatiotemporal location will be effective according to the repertoire of receptors and intracellular signaling cascades available to that cell population. Previous attempts to find a correlation between neurotrophic factor requirement and neuronal type have been unsuccessful. The state space model of neurotrophic factor interactions will allow to search for multifactorial correlations between phenotypically or lineage-wise related neuronal types and their respective neurotrophic requirements, that is, their coordinates in the state space.

\section{References}

Acland P, Dixon M, Peters G, Dickson C (1990) Subcellular fate of the Int-2 oncoprotein is determined by choice of initiation codon. Nature 343:662-665.

Alderson RF, Alterman AL, Barde YA, Lindsay RM (1990) Brainderived neurotrophic factor increases survival and differentiated functions of rat septal cholinergic neurons in culture. Neuron 5:297-306.

Anderson DJ (1989) New roles for PDGF and CNTF in controlling the timing of glial cell differentiation in the optic nerve. Trends Neurosci $12: 83-85$.

Arakawa Y, Sendtner M, Thoenen H (1990) Survival effect of ciliary neurotrophic factor (CNTF) on chick embryonic motoneurons in culture: comparison with other neurotrophic factors and cytokines. $\mathbf{J}$ Neurosci 10:3507-3515.

Araujo DM, Cotman CW (1992) Basic FGF in astroglial, microglial, and neuronal cultures: characterization of binding siles and modulation of release by lymphokines and trophic factors. J Neurosci 12: 1668-1678.

Barbin G, Manthorpe M, Varon S (1984) Purification of the chick eye ciliary neuronotrophic factor. J Neurochem 43:1468-1478.

Bazan JF (1991) Neuropoietic cytokines in the hematopoietic fold. Neuron 7:197-208.

Bellot F, Crumley G, Kaplow JM, Schlessinger J, Jaye M, Dionne CA (1991) Ligand-induced transphosphorylation between different FGF receptors. EMBO J 10:2849-2854.

Berkemeier LR, Winslow JW, Kaplan DR, Nikolics K, Goeddel DV, Rosenthal A (1991) Neurotrophin-5: a novel neurotrophic factor that activates $t r k$ and $t r k \mathrm{~B}$. Neuron 7:857-866.

Birren SJ, Anderson DJ (1990) A v-myc-immortalized sympathoadrenal progenitor cell line in which neuronal differentiation is initiated by FGF but not NGF. Neuron 4:189-201.

Birren SJ, Verdi JM, Anderson DJ (1992) Membrane depolarization induces p140trk and NGF responsiveness, but not p75LNGFR, in MAH cells. Science 257:395-397. 
Blottner D, Bruggemann W, Unsicker K (1989) Ciliary neurotrophic factor supports target-deprived preganglionic sympathetic spinal cord neurons. Neurosci Lett 105:316-320.

Brown MC, Perry VH, Lunn ER, Gordon S, Heumann R (1991) Macrophage dependence of peripheral sensory nerve regeneration: possible involvement of nerve growth factor. Neuron 6:359-370.

Campenot RB, Walji AH, Draker DD (1991) Effects of sphingosine, staurosporine, and phorbol ester on neurites of rat sympathetic neurons growing in compartmented cultures. J Neurosci 11:1126-1139.

Castrén E, Zafra F, Thoenen H, Lindholm D (1992) Light regulates expression of brain-derived neurotrophic factor $\mathrm{mRNA}$ in rat visual cortex. Proc Natl Acad Sci USA 89:9444-9448.

Cattaneo E, McKay R (1990) Proliferation and differentiation of neuronal stem cells regulated by nerve growth factor. Nature 347:762765 .

Chao MV (1992) Growth factor signaling: where is the specificity? Cell 68:995-997.

Cohen-Cory S, Dreyfus CF, Black IB (1991) NGF and excitatory neurotransmitters regulate survival and morphogenesis of cultured cerebellar Purkinje cells. J Neurosci 11:462-471.

Cordon-Cardo C, Tapley P, Jing SQ, Nanduri V, O'Rourke E, I amballe F, Kovary K, Klein R, Jones KR, Reichardt LF, Barbacid M (1991) The trk tyrosine protein kinase mediates the mitogenic properties of ncrve growth factor and neurotrophin-3. Cell 66:173-183.

Davis S, Aldrich TH, Valenzuela DM, Wong VV, Furth ME, Squinto SP, Yancopoulos GD (1991) The receptor for ciliary neurotrophic factor. Science 253:59-63.

Diamond J, Foerster A, Holmes A, Coughlin M (1992) Sensory nerves in adult rats regenerate and restore sensory function to the skin independently of endogenous NGF. J Neurosci 12:1467-1476.

DiStefano PS, Friedman B, Radziejewski C, Alexander C, Boland P, Schick CM, Lindsay RM, Wiegand SJ (1992) The neurotrophins BDNF, NT-3, and NGF display distinct patterns of retrograde axonal transport in peripheral and central neurons. Neuron 8:983-993.

Drago J, Murphy M, Carroll SM, Harvey RP, Bartlett PF (1991) Fibroblast growth factor-mediated proliferation of central nervous system precursors depends on endogenous production of insulin-like growth factor I. Proc Natl Acad Sci USA 88:2199-2203.

Dugich-Djordjevic MM, Tocco G, Willoughby DA, Najm I, Pasinetti G, Thompson RF, Baudry M, Lapchak PA, Hefti F (1992) BDNF mRNA expression in the developing rat brain following kainic acidinduced seizure activity. Neuron 8:1127-1138.

Eckenstein FP, Esch F, Holbert T, Blacher RW, Nishi R (1990) Purification and characterization of a trophic factor for embryonic peripheral neurons: comparison with fibroblast growth factors. Neuron 4:623-631.

Elde R, Cao Y, Cintra A, Brelje TC, Pelto Huikko M, Junttila T, Fuxe K, Pettersson RF, Hökfelt T (1991) Prominent expression of acidic fibroblast growth factor in motor and sensory neurons. Neuron 7:349_ 364.

Engele J, Bohn MC (1991) The neurotrophic effects of fibroblast growth factors on dopaminergic neurons in vitro are mediated by mesencephalic glia. J Neurosci 11:3070-3078.

Ernfors P, Ibáñez CF, Ebendal T, Olson L, Persson H (1990a) Molecular cloning and neurotrophic activities of a protein with structural similarities to nerve growth factor: developmental and topographical expression in brain. Proc Natl Acad Sci USA 87:5454-5458.

Ernfors P, Wetmore C, Olson L, Persson H (1990b) Identification of cells in rat brain and peripheral tissues expressing mRNA for members of the nerve growth factor family. Neuron 5:511-526.

Ernsberger U, Rohrer H (1988) Neuronal precursor cells in chick dorsal root ganglia: differentiation and survival in vitro. Dev Biol 126: $420-432$

Ernsberger U, Edgar D, Rohrer H (1989a) The survival of early chick sympathetic neurons in vitro is dependent on a suitable substrate but independent of NGF. Dev Biol 135:250-262.

Ernsberger U, Sendtner M, Rohrer H (1989b) Proliferation and differentiation of embryonic chick sympathetic neurons: effects of ciliary neurotrophic factor. Neuron 2:1275-1284.

Ferguson IA, Schweitzer JB, Johnson EM (1990) Basic fibroblast growth factor: receptor-mediated internalization, metabolism, and anterograde axonal transport in retinal ganglion cells. J Neurosci 10:21762189 .

Fischer W, Björklund A, Chen K, Gage FH (1991) NGF improves spatial memory in aged rodents as a function of age. J Neurosci 11: 1889-1906.
Freidin M, Bennett MVL, Kessler JA (1992) Cultured sympathetic neurons synthesize and release the cytokine interleukin $1 \beta$. Proc Natl Acad Sci USA 89:10440-10443.

Friedman B, Scherer SS, Rudge JS, Helgren M, Morrisey D, McClain J, Wang D-Y, Wiegand SJ, Furth ME, Lindsay RM, Ip NY (1992) Regulation of ciliary neurotrophic factor expression in myelin-related Schwann cells in vivo. Neuron 9:295-305.

Gearing DP, Thut CJ, VandenBos T, Gimpel SD, Delaney PB, King J, Price V, Cosman D, Beckmann MP (1991) Leukemia inhibitory factor receptor is structurally related to the IL-6 signal transducer, gp130. EMBO J 10:2839-2848.

Gearing DP, Comeau MR, Friend DJ, Gimpel SD, Thut CJ, McGourty J, Brasher KK, King JA, Gillis S, Mosley B, Ziegler SF, Cosman D (1992) The IL-6 signal transducer, gp130: an oncostatin M receptor and affinity converter for the LIF receptor. Science 255:1434-1437.

Gómez-Pinilla F, Lee JW-K, Cotman CW (1992) Basic FGF in adult rat brain: cellular distribution and response to entorhinal lesion and fimbria-fornix transection. J Neurosci 12:345-355.

Greene LA, Volonte C, Chalazonitis A (1990) Purine analogs inhibit nerve growth factor-promoted neurite outgrowth by sympathetic and sensory neurons. J Neurosci 10:1479-1485.

Gurney ME, Yamamoto H, Kwon Y (1992) Induction of motor neuron sprouting in vivo by ciliary neurotrophic factor and basic fibroblast growth factor. J Neurosci 12:3241-3247.

Hageman GS, Kirchoff-Rempe MA, Lewis GP, Fisher SK, Anderson DH (1991) Sequestration of basic fibroblast growth factor in the primate retinal interphotoreceptor matrix. Proc Natl Acad Sci USA 88:6706-6710.

Hagg T, Quon D, Higaki J, Varon S (1992) Ciliary neurotrophic factor prevents neuronal degeneration and promotes low affinity NGF receptor expression in the adult rat CNS. Neuron 8:145-158.

Hallböök F, Ibáñez CF, Persson H (1991) Evolutionary studies of the nerve growth factor family reveal a novel member abundantly expressed in Xenopus ovary. Neuron 6:845-858.

Hatten ME, Lynch M, Rydel RE, Sanchez J, Joseph-Silverstein J, Moscatelli D, Rifkin DB (1988) In vitro neurite extension by granule neurons is dependent upon astroglial-derived fibroblast growth factor. Dev Biol 125:280-289.

Hendry IA, Murphy M, Hilton DJ, Nicola NA, Bartlett PF (1992) Binding and retrograde transport of leukemia inhibitory factor by the sensory nervous system. J Neurosci 12:3427-3434.

Herrup K, Sunter K (1987) Numerical matching during cerebellar development: quantitative analysis of granule cell death in staggerer mouse chimeras. J Neurosci 7:829-836.

Heuer JG, von Bartheld CS, Kinoshita Y, Evers PC, Bothwell M (1990) Alternating phases of FGF receptor and NGF receptor expression in the developing chicken nervous system. Neuron 5:283-296.

Heumann R, Lindholm D, Bandtlow C, Meyer M, Radeke MJ, Misko TP, Shooter E, Thoenen H (1987) Differential regulation of mRNA encoding nerve growth factor and its receptor in rat sciatic nerve during development, degeneration, and regeneration: role of macrophages. Proc Natl Acad Sci USA 84:8735-8739.

Hohn A, Leibrock J, Bailey K, Barde YA (1990) Identification and characterization of a novel member of the nerve growth factor/brainderived neurotrophic factor family. Nature 344:339-341.

Holtzman DM, Li Y, Parada LF, Kinsman S, Chen C-K, Valletta JS, Zhou J, Long JB, Mobley WC (1992) pl40trk mRNA marks NGFresponsive forebrain neurons: evidence that trk gene expression is induced by NGF. Neuron 9:465-478.

Hyman C, Hofer M, Barde Y-A, Juhasz. M, Yancopoulos GD, Squinto SP, Lindsay RM (1991) BDNF is a neurotrophic factor for dopaminergic neurons of the substantia nigra. Nature 350:230-232.

Ibáñez CF, Ebendal T, Barbany G, Murray Rust J, Blundell TL, Persson H (1992) Disruption of the low affinity receptor-binding site in NGF allows neuronal survival and differentiation by binding to the trk gene product. Cell 69:329-341.

Ip NY, Nye SH, Boulton TG, Davis S, Taga T, Li Y, Birren SJ, Yasukawa K, Kishimoto T, Anderson DJ, Stahl N, Yancopoulos GD (1992) CNTF and LIF act on neuronal cells via shared signaling pathways that involve the IL-6 signal transducing receptor component gp130. Cell 69:1121-1132.

Jackson A, Friedman S, Zhan X, Engleka KA, Forough R, Maciag T (1992) Heat shock induces the release of fibroblast growth factor 1 from NIH 3T3 cells. Proc Natl Acad Sci USA 89:10691-10695.

Johnson EM, Osborne PA, Taniuchi M (1989) Destruction of sympathetic and sensory neurons in the developing rat by a monoclonal 
antibody against the nerve growth factor (NGF) receptor. Brain Res 478:166-170.

Kalcheim C (1989) Basic fibroblast growth factor stimulates survival of nonneuronal cells developing from trunk neural crest. Dev Biol 134:1-10.

Kalcheim C, Carmeli C, Rosenthal A (1992) Neurotrophin 3 is a mitogen for cultured neural crest cells. Proc Natl Acad Sci USA 89: $1661-1665$.

Katz DM, Erb M, Lillis R, Neet K (1990) Trophic regulation of nodose ganglion cell development: cvidence for an expanded role of nerve growth factor during embryogenesis in the rat. Exp Neurol 110:1-10.

Klagsbrun M, Baird A (1991) A dual receptor system is required for basic fibroblast growth factor activity. Cell 67:229-231.

Klein R, Conway D, Parada LF, Barbacid M (1990a) The $t r k B$ tyrosine protein kinase gene codes for a second neurogenic receptor that lacks the catalytic kinase domain. Cell 61:647-656.

Klein R, Martin-Zanca D, Barbacid M, Parada LF (1990b) Expression of the tyrosine kinase receptor gene $\operatorname{trkB}$ is confined to the murine embryonic and adult nervous system. Development 109:845-850.

Klein R, Nanduri V, Jing SA, Lamballe F, Tapley P, Bryant S, CordonCardo C, Jones KR, Reichardt LF, Barbacid M (1991) The trkB tyrosine protein kinase is a receptor for brain-derived neurotrophic factor and neurotrophin-3. Cell 66:395-403.

Klein R, Lamballe F, Bryant S, Barbacid M (1992) The trkB tyrosine protein kinase is a receptor for neurotrophin-4. Neuron 8:947-956.

Knüsel B, Winslow JW, Rosenthal A, Burton LE, Seid DP, Nikolics K, Hefti $F$ (1991) Promotion of central cholinergic and dopaminergic neuron differentiation by brain-derived neurotrophic factor but not neurotrophin 3. Proc Natl Acad Sci USA 88:961-965.

Korsching S (1986) The role of nerve growth factor in the CNS. Trends Neurosci 9:570-573.

Korsching S, Thoenen H (1983) Nerve growth factor in sympathetic ganglia and corresponding target organs of the rat: correlation with density of sympathetic innervation. Proc Natl Acad Sci USA 80: 3513-3516.

Korsching S, Thoenen H (1985) Nerve growth factor supply for sensory neurons: site of origin and competition with the sympathetic nervous system. Neurosci Lett 54:201-205.

Lamballe F, Klein R, Barbacid M (1991) trkC, a new member of the trk family of tyrosine protein kinases, is a receptor for neurotrophin3. Cell 66:967-979.

Lee K-F, Li E, Huber LJ, Landis SC, Sharpe AH, Chao MV, Jaenisch $R$ (1992) Targeted mutation of the gene encoding the low affinity NGF receptor $\mathrm{p} 75$ leads to deficits in the peripheral sensory nervous system. Cell 69:737-749.

Leibrock J, I.ottspeich F, Hohn A, Hofer M, Hengerer B, Masiakowski P, Thoenen H, Barde YA (1989) Molecular cloning and expression of brain-derived neurotrophic factor. Nature 341:149-152.

Leung DW, Parent AS, Cachianes G, Esch F, Coulombe JN, Nikolics K, Eckenstein FP, Nishi R (1992) Cloning, expression during development, and evidence for release of a trophic factor for ciliary ganglion neurons. Neuron 8:1045-1053.

Levi-Montalcini R (1987) The nerve growth factor 35 years later. Science 237:1154-1162.

Lillien LE, Claude P (1985) Nerve growth factor is a mitogen for cultured chromaffin cells. Nature 317:632-634.

Lin LF, Armes LG, Sommer A, Smith DJ, Collins F (1990) Isolation and characterization of ciliary neurotrophic factor from rabbit sciatic nerves. J Biol Chem 265:8942-8947.

Lindsay RM (1988) The role of neurotrophic growth factors in development, maintenance, and regeneration of sensory neurons. In: The making of the nervous system (Parnavelas JG, Stern CD, Stirling RV, eds), pp 148-165. Oxford: Oxford UP.

Lindsay RM, Thoenen H, Barde Y-A (1985) Placode and neural crestderived sensory neurons are responsive at early developmental stages to brain-derived neurotrophic factor. Dev Biol 112:319-328.

Lipton SA, Kater SB (1989) Neurotransmitter regulation of neuronal outgrowth, plasticity and survival. Trends Neurosci 12:265-270.

Lipton SA, Wagner JA, Madison RD, D'Amore PA (1988) Acidic fibroblast growth factor enhances regeneration of processes by postnatal mammalian retinal ganglion cells in culture. Proc Natl Acad Sci USA 85:2388-2392.

Maisonpierre PC, Belluscio L, Friedman B, Alderson RF, Wiegand SJ, Furth ME, Lindsay RM, Yancopoulos GD (1990a) NT-3, BDNF, and NGF in the developing rat nervous system: parallel as well as reciprocal patterns of expression. Neuron 5:501-509.
Maisonpierre PC, Belluscio L, Squinto S, Ip NY, Furth ME, Lindsay KM, Yancopoulos GD (1990b) Neurotrophin-3: a neurotrophic factor related to NGF and BDNF. Science 247:1446-1451.

Martinou J-C, Martinou I, Kato AC (1992) Cholinergic differentiation factor (CDF/LIF) promotes survival of isolated rat embryonic motoneurons in vitro. Neuron 8:737-744.

Matsuoka I, Meyer M, Thoenen H (1991) Cell-type-specific regulation of nerve growth factor (NGF) synthesis in non-neuronal cells: comparison of Schwann cells with other cell types. J Neurosci 11:31653177.

Meiri KF, Burdick D (1991) Nerve growth factor stimulation of GAP43 phosphorylation in intact isolated growth cones. J Neurosci 11: 3155-3164.

Miki T, Bottaro DP, Fleming TP, Smith CL, Burgess WH, Chan AML, Aaronson SA (1992) Determination of ligand-binding specificity by alternative splicing: two distinct growth factor receptors encoded by a single gene. Proc Natl Acad Sci USA 89:246-250.

Miller FD, Mathew TC, Toma JG (1991) Regulation of nerve growth factor receptor gene expression by nerve growth factor in the developing peripheral nervous system. J Cell Biol 112:303-312.

Mobley WC, Woo JE, Edwards RH, Riopelle RJ, Longo FM, Weskamp G, Otten U, Valletta JS, Johnston MV (1989) Developmental regulation of nerve growth factor and its receptor in the rat caudateputamen. Neuron 3:655-664.

Muesch A, Hartmann E, Rohde K, Rubartelli A, Sitia R, Rapaport TA (1990) A novel pathway for secretory proteins? Trends Biochem Sci 15:86-88.

Murphy M, Reid K, Hilton DJ, Bartlett PF (1991) Generation of sensory neurons is stimulated by leukemia inhibitory factor. Proc Natl Acad Sci USA 88:3498-3501.

Oppenheim RW (1991) Cell death during development of the nervous system. Annu Rev Neurosci 14:453-501.

Oppenheim RW, Prevette D, Fuller F (1992) The lack of effect of basic and acidic fibroblast growth factors on the naturally occurring death of neurons in the chick embryo. J Neurosci 12:2726-2734.

Otten U, Ehrhard P, Peck R (1989) Nerve growth factor induces growth and differentiation of human B lymphocytes. Proc Natl Acad Sci USA 86:10059-10063.

Pearce FL, Thompson HL (1986) Some characteristics of histamine secretion from rat peritoneal mast cells stimulated with nerve growth factor. J Physiol (Lond) 372:379-393.

Purves D (1986) The trophic theory of neural connections. Trends Neurosci 9:486-489.

Radeke MJ, Feinstein SC (1991) Analytical purification of the slow, high affinity NGF receptor: identification of a novel $135 \mathrm{kd}$ polypeptide. Neuron 7:141-150.

Radeke MJ, Misko TP, Hsu C, Herzenberg LA, Shooter EM (1987) Gene transfer and molecular cloning of the rat nerve growth factor receptor. Nature 325:593-597.

Rao MS, Landis SC, Patterson PH (1990) The cholinergic neuronal differentiation factor from heart cell conditioned medium is different from the cholinergic factors in sciatic nerve and spinal cord. Dev Biol 139:65-74.

Rifkin DB, Moscatelli D (1989) Recent developments in the cell biology of basic fibroblast growth factor. J Cell Biol 109:1-6.

Rodríguez-Tébar A, Jeffrey PL, Thoenen H, Barde YA (1989) The survival of chick retinal ganglion cells in response to brain-derived neurotrophic factor depends on their embryonic age. Dev Biol 136: 296-303.

Rodríguez-Tébar A, Dechant G, Götz. R, Barde YA (1992) Binding of neurotrophin-3 to its neuronal receptors and interactions with nerve growth factor and brain-derived neurotrophic factor. EMBO J 11: 917-922.

Rosenthal A, Goeddel DV, Nguyen T, Lewis M, Shih A, Laramee GR, Nikolics K, Winslow JW (1990) Primary structure and biological activity of a novel human neurotrophic factor. Neuron 4:767-773.

Ruit KG, Osborne PA, Schmidt RE, Johnson EM, Snider WD (1990) Nerve growth factor regulates sympathetic ganglion cell morphology and survival in the adult mouse. J Neurosci 10:2412-2419.

Ruit KG, Elliott JL, Osborne PA, Yan Q, Snider WD (1992) Selective dependence of mammalian dorsal root ganglion neurons on nerve growth factor during embryonic development. Neuron 8:573-587.

Rydel RE, Greene LA (1987) Acidic and basic fibroblast growth factors promote stable neurite outgrowth and neuronal differentiation in cultures of PC12 cells. J Neurosci 7:3639-3653.

Saad B, Constam DB, Ortmann R, Moos M, Fontana A, Schachner M 
(1991) Astrocyte-derived TGF- $\beta 2$ and NGF differentially regulate neural recognition molecule expression by cultured astrocytes. J Cell Biol 115:473-484.

Satoh T, Nakamura S, Taga T, Matsuda T, Hirano T, Kishimoto T, Kaziro Y (1988) Induction of neuronal differentiation in $\mathrm{PC1} 2$ cells by B-cell stimulatory factor 2/interleukin 6 . Mol Cell Biol 8:35463549 .

Schecterson LC, Bothwell M (1992) Novel roles for neurotrophins are suggested by BDNF and NT-3 mRNA expression in developing neurons. Neuron 9:449-463.

Schnürch H, Risau W (1991) Differentiating and mature neurons express the acidic fibroblast growth factor gene during chick neural development. Development 111:1143-1154.

Segal RA, Takahashi H, McKay RDG (1993) Changes in neurotrophin responsiveness during the development of cerebellar granule neurons. Neuron, in press.

Selby MJ, Edwards R, Sharp F, Rutter WJ (1987) Mouse nerve growth factor gene: structure and expression. Mol Cell Biol 7:3057-3064.

Sendtner M, Holtmann B, Kolbeck R, Thoenen H, Barde Y-A (1992) Brain-derived neurotrophic factor prevents the death of motoneurons in newborn rats after nerve section. Nature 360:757-759.

Sieber-Blum M (1991) Role of the neurotrophic factors BDNF and NGF in the commitment of pluripotent neural crest cells. Neuron 6:949-955.

Smith AG, Nichols J, Robertson M, Rathjen PD (1992) Differentiation inhibiting activity (DIA/LIF) and mouse development. Dev Biol 151: 339-351.

Soppet D, Escandon E, Maragos J, Middlemas DS, Reid SW, Blair J Burton LE, Stanton BR, Kaplan DR, Hunter T, Nikolics K, Parada LF (1991) The neurotrophic factors brain-derived neurotrophic factor and neurotrophin-3 are ligands for the trkB tyrosine kinase receptor. Cell 65:895-903.

Squinto SP, Stitt TN, Aldrich TH, Davis S, Bianco SM, Radziejewski C, Glass DJ, Masiakowski P, Furth ME, Valenzuela DM, DiStefano PS, Yancopoulos GD (1991) $t r k B$ encodes a functional receptor for brain-derived neurotrophic factor and neurotrophin-3 but not nerve growth factor. Cell 65:885-893.

Stocker KM, Sherman L, Rees S, Ciment G (1991) Basic FGF and TGF-beta 1 influence commitment to melanogenesis in neural crestderived cells of avian embryos. Development 111:635-645

Stöckli KA, Lillien LE, Näher-Noé M, Breitfeld G, Hughes RA, Raff MC, Thoenen H, Sendtner M (1991) Regional distribution, developmental changes, and cellular localization of CNTF-mRNA and protein in the rat brain. J Cell Biol 115:447-459.

Thoenen H, Bandtlow C, Heumann R (1987) The physiological function of nerve growth factor in the central nervous system: comparison with the periphery. Rev Physiol Biochem Pharmacol 109:145-178.
Vainikka S, Partanen J, Bellosta P, Coulier F, Basilico C, Jaye M, Alitalo K (1992) Fibroblast growth factor receptor-4 shows novel features in genomic structure, ligand binding and signal transduction. EMBO $\mathrm{J}$ 11:4273-4280.

Vantini G, Schiavo N, Di Martino A, Polato P, Triban C, Callegaro L, Toffano G, Leon A (1989) Evidence for a physiological role of nerve growth factor in the central nervous system of neonatal rats. Neuron 3:267-273.

Vlodavsky I, Bar Shavit R, Ishai Michaeli R, Bashkin P, Fuks Z (1991) Extracellular sequestration and release of fibroblast growth factor: regulatory mechanism? Trends Biochem 16:268-271.

Vogel KS, Davies AM (1991) The duration of neurotrophic factor independence in early sensory neurons is matched to the time course of target field innervation. Neuron 7:819-830.

Wayne DB, Heaton MB (1990) The response of cultured trigeminal and spinal cord motoneurons to nerve growth factor. Dev Biol 138: 473-483.

Weskamp G, Reichardt LF (1991) Evidence that biological activity of NGF is mediated through a novel subclass of high affinity receptors. Neuron 6:649-663.

Wetmore C, Cao Y, Pettersson RF, Olson L (1991) Brain-derived neurotrophic factor: subcellular compartmentalization and interneuronal transfer as visualized with anti-peptide antibodies. Proc Natl Acad Sci USA 88:9843-9847.

Wheeler EF, Bothwell M (1992) Spatiotemporal patterns of expression of NGF and the low-affinity NGF receptor in rat embryos suggest functional roles in tissue morphogenesis and myogenesis. J Neurosci 12:930-945.

Wilkinson DG, Bhatt S, McMahon AP (1989) Expression pattern of the FGF-related proto-oncogene int-2 suggests multiple roles in fetal development. Development 105:131-136.

Wright EM, Vogel KS, Davies AM (1992) Neurotrophic factors promote the maturation of developing sensory neurons before they become dependent on these factors for survival. Neuron 9:139-150.

Yaar M, Grossman K, Eller M, Gilchrest BA (1991) Evidence for nerve growth factor-mediated paracrine effects in human epidermis. J Cell Biol 115:821-828.

Yamamori T, Fukada K, Aebersold R, Korsching S, Fann M-J, Patterson PH (1989) The cholinergic neuronal differentiation factor from heart cells is identical to leukemia inhibitory factor. Science 246: 1412-1416.

Yarden Y, Kelman Z (1991) Transmembrane signalling for cytokines and growth factors. Curr Opin Struct Biol 1:582-589.

Yoshida K, Gage FH (1991) Fibroblast growth factors stimulate nerve growth factor synthesis and secretion by astrocytes. Brain Res 538: 118-126. 